\title{
Dry matter productivity and bromatological quality of ryegrass genotypes cultivated in southern Brazil
}

[Produtividade de matéria seca e qualidade bromatológica de genótipos de azevém cultivados no Sul do Brasil]

\author{
A.R. Ramos $^{1}$, A. Zampar $^{2}$, A.W.L. Silva ${ }^{2 *}$ \\ ${ }^{1}$ Cooperativa Agroindustrial Alfa - Chapecó, SC \\ ${ }^{2}$ Universidade do Estado de Santa Catarina - Chapecó, SC
}

\begin{abstract}
The goal of this work was to assess the biomass production and bromatological quality of ryegrass genotypes in ten municipalities of the Western and North Plateau regions of the State of Santa Catarina, Brazil. The cultivars La Estanzuela 284 (diploid), Bar HQ, Barjumbo, INIA Escorpio, Potro, and Winter Star (tetraploids) were compared, distributed in a randomized block design, in which the municipalities constituted the blocks, with three replications. The cuts were performed when the plants reached $30 \mathrm{~cm}$, leaving a residue of $10 \mathrm{~cm}$. In three cuts, the cultivars Barjumbo and Bar HQ were the most productive, exceeding $4.6 \mathrm{t} \mathrm{ha}^{-1}$ of dry matter. In the places in which five cuts were performed, the production of these cultivars exceeded $7.3 \mathrm{t} \mathrm{ha}^{-1}$, placing them again ahead of the others. The average crude protein content in three cuts was greater than $25 \%$ in all cultivars. There was no difference between the genotypes in the content of neutral detergent fiber and total digestible nutrients. There was a significant correlation between quantitative and qualitative productive variables. The assessed cultivars represented good options for composing short-term or long-term winter-feeding systems, adjusted to the integration with annual crops or warm-season pastures.
\end{abstract}

Keywords: cultivars, diploid, Lolium multiflorum, tetraploid, nutritional value

\section{RESUMO}

O objetivo deste trabalho foi avaliar a produção de biomassa e qualidade bromatológica de genótipos de azevém, em dez municípios das regiões Oeste e Planalto Norte Catarinense, Estado de Santa Catarina, Brasil. Foram comparados os cultivares La Estanzuela 284 (diploide), Bar HQ, Barjumbo, INIA Escorpio, Potro e Winter Star (tetraploides), distribuídos em um delineamento blocos casualizados, em que os municípios constituíram os blocos, com três repetições. Os cortes foram realizados quando as plantas atingiram $30 \mathrm{~cm}$, deixando um resíduo de $10 \mathrm{~cm}$. Sob três cortes, os cultivares Barjumbo e Bar HQ foram os mais produtivos, ultrapassando 4,6 tha ${ }^{-1}$ de matéria seca. Nos locais em que ocorreram cinco cortes, a produção destes cultivares superou 7,3 tha ${ }^{-1}$, posicionando-os novamente à frente dos demais. O teor médio de proteína bruta em três cortes foi superior a $25 \%$ em todos os cultivares. Não houve diferença entre os genótipos no teor de fibra detergente neutro e de nutrientes digestíveis totais. Verificou-se correlação significativa entre variáveis produtivas quantitativas $e$ qualitativas. Os cultivares testados representam boas opções para compor sistemas forrageiros hibernoprimaveris de curta ou longa duração, ajustando-se à integração com lavouras ou pastagens anuais de estação quente.

Palavras-chave: cultivares, diploide, Lolium multiflorum, tetraploide, valor nutritivo

\section{INTRODUCTION}

Due to its numerous positive characteristics, ryegrass (Lolium multiflorum Lam.) is classified by Carvalho et al. (2013) as "the most important forage for the agricultural context of southern
Brazil" (p.495). It is used both for grazing and for production of conserved forage, isolated or in intercrop cultivation. Ryegrass also composes crop-livestock integration systems and can be sowed over perennial warm-season grasses (Hahn et al., 2015). With a production cycle that extends

Recebido em 20 de março de 2020

Aceito em 4 de julho de 2020

*Autor para correspondência (corresponding author)

E-mail: awls12@hotmail.com 
between winter and spring, it provides forage of excellent bromatological quality for a long period. Ryegrass genotypes are divided into diploid and tetraploid materials. The later have fast initial production, longer vegetative cycle, higher mass production and greater relationship between content and cell wall, which determines higher levels of soluble carbohydrates and proteins, as well as greater digestibility (Oliveira et al., 2014, 2015; Marchesan et al., 2016).

On the other hand, there is a substantial difference in the cost of pasture production, particularly with regard to the price of seeds, which is much higher in tetraploid cultivars. It is worth mentioning that comparative assessments between ryegrass cultivars have been performed for over twenty years (Tcacenco, 1995), and intensified in recent years, given the wide variety of genotypes in the market (Tonetto et al., 2011; Kroning et al., 2014; Mioto et al., 2014; Oliveira et al., 2014; 2015; Hahn et al., 2015).The extensive use of ryegrass in milk production systems has promoted obtaining more information about genotypes with higher production and biomass quality. This fact has helped reduce production costs and enhance productivity by areas. This is extremely important in the State of Santa Catarina, Brazil, where 89\% of farms have up to 50 ha (Censo..., 2018), which requires high efficiency in the use of available space. In view of the context above described, the goal of the present study was to assess the biomass production and bromatological quality of ryegrass genotypes submitted to different number of cuts in southern Brazil.

\section{MATERIAL AND METHODS}

The experiment that resulted in the present work was approved by the Animal Ethics and Experimentation Committee of the University of the State of Santa Catarina (UDESC), Brazil, under protocol CEUA $n^{\circ}$ 7354280716. The research was conducted in ten rural properties of the West and North Plateau regions of the State of Santa Catarina, Brazil, located in the following municipalities, geographical coordinates, and altitude of the experiment sites: Abelardo Luz

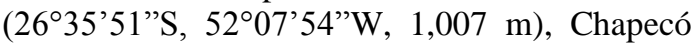
$\left(27^{\circ} 05^{\prime} 30^{\prime \prime} \mathrm{S}, 53^{\circ} 00^{\prime} 40^{\prime \prime} \mathrm{W}, 600 \mathrm{~m}\right)$, Guaraciaba

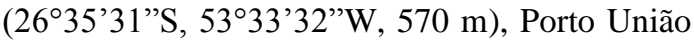
(2620'53”S, 5051'04”W, $763 \mathrm{~m}$ ), Quilombo (264'14”S, 52॰42'05'”, $425 \mathrm{~m})$, São Bernardino (26 $\left.29^{\circ} 04^{\prime \prime} \mathrm{S}, 52^{\circ} 58^{\prime} 51^{\prime \prime} \mathrm{W}, 806 \mathrm{~m}\right)$,
São Lourenço do Oeste (26³9'59'S, 52॰53'40”'W, $809 \mathrm{~m}$ ), São Miguel do Oeste (2642'05'S, 5336'23'W, $535 \mathrm{~m}$ ), Xanxerê (26 $53^{\circ}$ '08'S, 52 25'08'W, $801 \mathrm{~m}$ ) and Xaxim (2659'43”'S, 52 32'25'W, $757 \mathrm{~m}$ ). According to Köppen classification (Alvares et al., 2013), Chapecó, Guaraciaba, Quilombo, São Bernardino, São Miguel do Oeste, and Xaxim are located in regions of $\mathrm{Cfa}$ climate (humid temperate climate with hot summer), whereas Abelardo Luz, Porto União, São Lourenço do Oeste, and Xanxerê are under Cfb climate (humid temperate climate with mild summer).

The assessments were performed from May to October 2016. Five tetraploid genotypes (Bar HQ, Barjumbo, INIA Escorpio, Potro, and Winter Star), and one diploid (La Estanzuela 284 or LE 284) were assessed. The parameters of soil fertility in the areas are illustrated in Table 1. Fertilization management was carried out following the recommendations provided by the Brazilian Society for Soil Science (Manual..., 2016) for cold season grasses, with an expected yield of $6 \mathrm{t} \mathrm{ha}^{-1}$ of dry matter (DM). Before sowing, four properties (three in Cfa climate and one in $\mathrm{Cfb}$ ) proceeded with organic fertilization. All properties carried out basic fertilization at sowing, as well as nitrogen cover fertilization after the first and/or second cut, using urea.

Sowing was carried out in May, between days 1 and 5 (Guaraciaba, Quilombo, and São Bernardino), day 19 (Abelardo Luz and Chapecó), days 22 to 25 (São Miguel do Oeste, Xanxerê and Xaxim), or in June (Porto União and São Lourenço do Oeste). Plots ranging from 1,000 to $2,000 \mathrm{~m}^{2}$ were used depending on the rural properties, cultivated by means of a seederfertilizer, with $17 \mathrm{~cm}$ row spacing. The sowing rate was $30 \mathrm{~kg} \mathrm{ha}^{-1}$ for the tetraploid genotypes (cultural value $=95.7 \%$ ) and $40 \mathrm{~kg} \mathrm{ha}^{-1}$ for LE 284 (cultural value $=68.3 \%$ ).

Before each grazing, when the plants reached $30 \mathrm{~cm}$ in height, samples were collected in order to assess forage production and nutritive value. In each sampling, 12 sub-samples of 1.5 linear meters were collected, with forage cut at $10 \mathrm{~cm}$ from to the ground. The heights were determined using a graduated stick. The samples from the area under grazing were weighed and conditioned in a forced air oven at $55^{\circ} \mathrm{C}$ for 72 hours, to determine the DM content. The dry samples were sent to the 
Labtron, laboratory of Cargill/Nutron, São Paulo, SP, Brazil, for bromatological analysis using near infrared reflectance spectroscopy. The contents of crude protein $\left(\right.$ slope $\left.=1.008, \mathrm{r}^{2}=0.975\right)$, neutral detergent fiber $(\mathrm{NDF})\left(\right.$ slope $\left.=1.000, \mathrm{r}^{2}=0.957\right)$ and total digestible nutrients (TDN) were determined, using net energy for lactation NEL = $(2.2 *(1.044-(0.0119 * \mathrm{ADF}))$, with ADF being the acid detergent fiber $\left(r^{2}=0.934\right)$. The result was applied in the formula TDN = $(89.796 * \mathrm{NEL} / 2.2)+4.898)$.

Table 1. Classification and parameters of soil fertility, according to analysis of the soils of the assessed areas with ryegrass genotypes, located in Abelardo Luz (AL), Chapecó (CH), Guaraciaba (GUA), Porto União (PU), Quilombo (QUI), São Bernardino (SB), São Lourenço do Oeste (SLO), São Miguel do Oeste (SMO), Xanxerê (XAN), and Xaxim (XAX)

\begin{tabular}{|c|c|c|c|c|c|c|c|c|c|c|}
\hline Local & $\mathrm{AL}$ & $\mathrm{CH}$ & GUA & PU & QUI & SB & SLO & SMO & $\mathrm{XAN}$ & XAX \\
\hline Soil classification $^{1}$ & DL & $\mathrm{EC}$ & $\mathrm{EC}$ & $\mathrm{DC}$ & $\mathrm{EC}$ & $\mathrm{EC}$ & EN & $\mathrm{EC}$ & DL & $\mathrm{DL}$ \\
\hline Clay $(\%)$ & 36.0 & 46.0 & 63.0 & 26.0 & 30.0 & 33.0 & 40.0 & 68.0 & 45.0 & 28.0 \\
\hline $\mathrm{pH}$ in water & 5.7 & 5.3 & 5.0 & 5.0 & 5.9 & 5.6 & 5.4 & 5.5 & 5.7 & 5.7 \\
\hline $\mathrm{P}\left(\mathrm{mg} \mathrm{dm}^{-3}\right)$ & 2.9 & 22.0 & 7.8 & 8.2 & 32.0 & 18.8 & 8.6 & 4.3 & 9.9 & 5.2 \\
\hline $\mathrm{K}\left(\mathrm{mg} \mathrm{dm}^{-3}\right)$ & 84.0 & 212.0 & 168.0 & 128.0 & 200.0 & 132.0 & 120.0 & 110.0 & 204.0 & 391.0 \\
\hline $\mathrm{OM} \mathrm{m} / \mathrm{v}(\%)$ & 5.5 & 3.9 & 3.5 & 5.1 & 2.9 & 2.6 & 3.3 & 2.5 & 4.6 & 2.8 \\
\hline $\mathrm{Al}\left(\mathrm{cmol}_{\mathrm{c}} \mathrm{dm}^{-3}\right)$ & 0.0 & 1.3 & 2.7 & 2.0 & 0.0 & 0.0 & 0.0 & 0.3 & 0.0 & 0.0 \\
\hline CEC pH $7.0\left(\mathrm{cmol} \mathrm{dm}^{-3}\right)$ & 13.3 & 15.8 & 11.7 & 21.5 & 21.0 & 16.6 & 14.7 & 14.7 & 12.0 & 23.0 \\
\hline Base Saturation (\%) & 79.3 & 76.0 & 67.8 & 66.3 & 76.7 & 82.7 & 84.5 & 66.8 & 75.4 & 78.7 \\
\hline
\end{tabular}

Following the field sampling, the animal stocking rate necessary for the consumption of the forage available in the assessed area was estimated using, as a criterion, a forage offer of $3.5 \%$ of the animals' live weight (LW). The lactating cows remained in the area until the total consumption of the produced and sampled forage, limited to one day in the paddock. In addition to ryegrass forage, the animals received supplementation (corn silage and/or grass hay) and concentrate. The present study did not measure milk production, and the animals were used only as a factor causing changes in the grazing environment, as "harvesters" of the forage produced. The day after grazing, the heights of residue were assessed in twelve points at random. In each point, where a height greater than $10 \mathrm{~cm}$ was found, this sample was cut to be subtracted from the weight of the forage produced. If a large unevenness of residue was found, the plots were levelled off with a mechanical mowing at $10 \mathrm{~cm}$ from the ground.

Sampling was carried out until the areas were destined for summer cultivation, promoting ryegrass desiccation in August or September for sowing corn silage, or desiccation in October or November, when the subsequent cultivation was annual summer pasture. In this way, the system used was the usual for the regions where the present study was conducted. Therefore, the number of cuts/grazing varied according to the assessed property. In four of them, three cuts were performed (Abelardo Luz, São Lourenço do Oeste, Porto União, and São Miguel do Oeste), in four properties there were four cuts (Chapecó, Quilombo, Xanxerê, and Xaxim), and in the others (Guaraciaba and São Bernardino) there were five cuts.

The experimental design was completely randomized blocks with six ryegrass genotypes as treatments, and considering the areas (municipalities) as blocks, with three repetitions. The mathematical model used was: $Y_{i j}=\mu+G_{i}+$ $\mathrm{B}_{\mathrm{j}}+\varepsilon_{\mathrm{ij}}$, where, $\mu$ is a constant common to all observations, $G_{i}$ is the effect of the $i$-th genotype, $B_{j}$ is the effect of the $j$-th block, and $\varepsilon_{i j}$ is a nonobservable random error assigned to $Y_{i j}$ observations. The dependent variables analyzed were DM produced by grazing cycle (cut), total DM production (total of cuts), average plant height with respect to the ground, forage accumulation rate per day or ARF (calculated by the total DM produced divided by the number of days between one cut and another), and bromatological quality for $\mathrm{CP}, \mathrm{NDF}$, and TDN. The normality of residues was determined, and the analysis of variance was subsequently performed. 
When a significant difference was detected, the Tukey test (5\%) was used to compare the treatment averages. Pearson's correlation coefficient was calculated to determine and estimate the existence of a relationship between the quantitative and qualitative productive variables. The statistical analyses were performed using the Statistical Analysis System software version 9.4 .

\section{RESULTS AND DISCUSSION}

In 2016, the Western and Northern Plateau regions of the State of Santa Catarina, Brazil, were subject to a typical winter (i.e., within the normal climactic conditions), with a reasonable frequency of low temperatures. Data from meteorological stations located in the area addressed by the present study indicated that, in May and June, the average of average temperatures in Cfa climate ranged from 0.3 to $0.9^{\circ} \mathrm{C}$ higher than the average of $\mathrm{Cfb}$ locations. On the other hand, from July to September, months in which the cuts were concentrated, this difference ranged from 1.6 to $3.1^{\circ} \mathrm{C}$. With respect to the minimum temperatures, the variation was even greater, and the monthly average from July to September in Cfa locations was 10.9, 12.7, and $11.8^{\circ} \mathrm{C}$ vs. $8.0,8.6$, and $9.1^{\circ} \mathrm{C}$ in $\mathrm{Cfb}$ locations.

The average interval between sowing and the first cut was $54.5 \pm 7.6$ days $(\mathrm{Cfa})$ and $62.8 \pm 9.7$ days (Cfb). In Cfa climate, Mioto et al. (2014) and Oliveira et al. (2014) had found a longer period (65 days and 75 days, respectively) whereas Tonetto et al. (2011) observed a similar interval (56 days), in all cases with a shorter cut height $(20 \mathrm{~cm})$, which demonstrates the precocity of the genotypes in the present study. Between the first cut (performed at the end of June or in July) and second cut (in August, in most places), the intervals were $29.2 \pm 2.3$ and $29.0 \pm 6.3$ days, whereas between the second and third cut (second half of August or September), they were $25.5 \pm$ 1.9 and $30.5 \pm 6.3$ days, respectively for Cfa and $\mathrm{Cfb}$ climate locations. The first and the third cuts were performed, on average, eight and five days before in Cfa condition, a fact associated with the minimum and average temperatures observed in each period.

The highest average DM accumulation rates, considering the entire period, were exhibited by the cultivars Barjumbo and Bar HQ, which exceeded INIA Escorpio, Potro, and Winter Star $(\mathrm{P}<0.05)$. Costa et al. (2013) recorded a higher DM accumulation rate in INIA Escorpio $(43.02 \mathrm{~kg}$ $\mathrm{ha}^{-1}$ day $\left.^{-1}\right)$; however, the DM accumulation rate observed in Barjumbo was similar to that observed by Marchesan et al. (2016). Barjumbo exhibited the highest production of DM in each cut and in the total of the three cuts, exceeding 4.8 $\mathrm{t} \mathrm{ha}^{-1}$, though without difference with respect to Bar HQ. In all assessments, INIA Escorpio produced significantly less DM than Barjumbo $(\mathrm{P}<0.05)$. The tetraploid materials Potro and Winter Star, as well as the diploid LE 284, exhibited intermediate productions.

The total DM production of Barjumbo, INIA Escorpio, Potro, and Winter Star were 10 to $18 \%$ lower than those observed by Hahn et al. (2015), also in three cuts. On the other hand, they surpassed by 37 to $138 \%$ those obtained by Flores et al. (2008) and Mioto et al. (2014) with LE 284, Barjumbo, and INIA Escorpio, also with three cuts. In absolute values, DM production increased over the period. In the first cut, the genotypes produced, on average, $1,024 \mathrm{~kg} \mathrm{ha}{ }^{-1}$. This productivity was increased by $40 \%$ in the second cut, and by $14 \%$ in the third cut, compared to the second. This variation had also been observed by Hahn et al. (2015) in four cuts, demonstrating that the production cycle of ryegrass is concentrated at the end of winter and spring.

However, it was found that the difference in production between the most and least productive genotypes decreased, varying from $58 \%$ to $31 \%$ from the first to the third cut, with $38 \%$ in the total of the three cuts. It is worth mentioning that the results of the present study were obtained in ten rural properties, which were subject to the most diverse edaphoclimatic conditions. Therefore, they were significantly representative of the average reality of the regions assessed. Table 2 illustrates the productive performance of the genotypes in three cuts, assessed in the ten properties in which the present study was conducted.

In two locations (Guaraciaba and São Bernardino), it was possible to assess the fourth cut (September) and fifth cut (second half of September or first half of October) (Table 3). Bar HQ and Barjumbo (tetraploid) cultivars showed higher DM production, both exceeding $7 \mathrm{t} \mathrm{ha}^{-1}$, and higher daily rates of accumulation $(\mathrm{P}<0.05)$. 
With two more assessment cycles, DM production increased from $2,747 \mathrm{~kg} \mathrm{ha}^{-1}$ (INIA Escorpio) to 4,264kg ha-1 (Bar HQ). Hahn et al. (2015), also with five cuts, did not find differences in production between Barjumbo, INIA Escorpio,
Potro, and Winter Star. On the other hand, Mioto et al. (2014) assessed nine cuts and observed the superiority of Barjumbo and INIA Escorpio in comparison to LE 284.

Table 2. Daily rate of dry matter productivity and accumulation in the first three cuts, and total of three cuts of ryegrass genotypes in ten municipalities in the Western and Northern Plateau regions of the State of Santa Catarina, Brazil

\begin{tabular}{|c|c|c|c|c|c|c|c|}
\hline & Bar HQ & Barjumbo & INIA Escorpio & LE 284 & Potro & Winter Star & p-value \\
\hline \multicolumn{8}{|c|}{ Daily dry matter accumulation rate $\left(\mathrm{kg} \mathrm{ha}^{-1}\right.$ day $\left.^{-1}\right)$} \\
\hline 1 & $22.14^{\mathrm{A}} \pm 9.94$ & $22.65^{\mathrm{A}} \pm 9.73$ & $15.05^{\mathrm{B}} \pm 6.54$ & $17.53^{\mathrm{B}} \pm 8.96$ & $14.85^{\mathrm{B}} \pm 6.82$ & & \\
\hline 2 & $53.89^{\mathrm{AB}} \pm 30.45$ & $56.65^{\mathrm{A}} \pm 33.67$ & $39.27^{\mathrm{C}_{ \pm}}$ & $46.08^{\mathrm{BC}} \pm 27.67$ & $46.31^{\mathrm{BC}} \pm 2$ & & 001 \\
\hline 3 & $67.92^{\mathrm{AB}} \pm 35.02$ & 71.39 & $55.84^{\mathrm{B}} \pm 25.26$ & $65.20^{\mathrm{AB}} \pm 36.84$ & $54.17^{\mathrm{B}} \pm 19$ & $\mathrm{~B} \pm 21.27$ & 0205 \\
\hline A & $47.99^{\mathrm{AB}} \pm 15.22$ & $50.23^{\mathrm{A}} \pm 14.90$ & $36.72^{\mathrm{C}} \pm 13.52$ & $42.94^{\mathrm{BC}} \pm 17.52$ & $38.44^{\mathrm{C}} \pm 10.51$ & $39.97^{\mathrm{C}} \pm 12.94$ & $<0.0001$ \\
\hline \multicolumn{8}{|c|}{ Dry matter productivity $\left(\mathrm{kg} \mathrm{ha}^{-1}\right)$} \\
\hline 1 & $1297.8^{\mathrm{A}} \pm 663.7$ & $1305.6^{\mathrm{A}} \pm 667.9$ & $866.6^{\mathrm{B}} \pm 439.5$ & $992.4^{\mathrm{B}} \pm 561.5$ & $858.5^{\mathrm{B}} \pm 437.3$ & $826.6^{\mathrm{B}} \pm 346.4$ & $<0.0001$ \\
\hline & $1587.1^{\mathrm{A}} \pm 991.2$ & $1667.3^{\mathrm{A}} \pm 1052.9$ & $1185.4^{\mathrm{B}} \pm 579.3$ & $1393.3^{\mathrm{AB}} \pm 905.6$ & $1333.9^{\mathrm{AB}} \pm 715.4$ & $1452.9^{\mathrm{AB}} \pm 790.6$ & 0.0015 \\
\hline & $1771.6^{\mathrm{AB}} \pm 809.5$ & $1874.6^{\mathrm{A}} \pm 780.3$ & $1482.5^{\mathrm{B}} \pm 662.7$ & $1718.8^{\mathrm{AB}} \pm 906.1$ & $1429.4^{\mathrm{AB}} \pm 485.9$ & $1566.2^{\mathrm{AB}} \pm 602.5$ & 0.0206 \\
\hline & $4654.5^{\mathrm{A}} \pm 1572.5$ & $4877.7^{\mathrm{A}} \pm 1493.6$ & $3534.7^{\mathrm{C}} \pm 1345.5$ & $4095.5^{\mathrm{B}} \pm 1627.0$ & $3632.9^{\mathrm{BC}} \pm 1085.1$ & $3788.9^{\mathrm{BC}} \pm 1298.5$ & $<0.0001$ \\
\hline
\end{tabular}

C: Cut (number); A: Average of three cuts; T: Total of three cuts.

Means followed by different letters in the line differ significantly by Tukey Test $(\mathrm{P}<0.05)$.

Table 3. Rate of daily dry matter productivity and accumulation in the fourth and fifth cuts, and the total of five cuts, in Guaraciaba and São Bernardino, Santa Catarina, Brazil

\begin{tabular}{rccccccc} 
C & Bar HQ & Barjumbo & $\begin{array}{c}\text { INIA } \\
\text { Escorpio }\end{array}$ & LE 284 & Potro & Winter Star & p-value \\
\hline \multicolumn{7}{c}{ Daily dry matter accumulation rate $\left(\mathrm{kg} \mathrm{ha}^{-1}\right.$ day $\left.^{-1}\right)$} \\
4 & $109.15^{\mathrm{A}} \pm 78.50$ & $97.01^{\mathrm{AB}} \pm 48.45$ & $75.89^{\mathrm{B}} \pm 38.82$ & $87.75^{\mathrm{AB}} \pm 57.60$ & $88.39^{\mathrm{AB}} \pm 58.55$ & $77.56^{\mathrm{AB}} \pm 38.99$ & 0.0162 \\
5 & $95.32^{\mathrm{A}} \pm 51.24$ & $102.53^{\mathrm{A}} \pm 58.74$ & $53.43^{\mathrm{C}} \pm 14.91$ & $67.08^{\mathrm{BC}} \pm 32.28$ & $90.08^{\mathrm{AB}_{ \pm}} \pm 48.85$ & $57.28^{\mathrm{C}} \pm 17.85$ & $<0.0001$ \\
$\mathrm{~A}$ & $62.53^{\mathrm{AB}} \pm 24.63$ & $65.68^{\mathrm{A}} \pm 27.21$ & $36.07^{\mathrm{C}} \pm 8.40$ & $42.07^{\mathrm{C}} \pm 9.22$ & $47.90^{\mathrm{BC}_{ \pm 1}}+13.91$ & $44.30^{\mathrm{C}} \pm 5.46$ & $<0.0001$
\end{tabular}

Dry matter productivity $\left(\mathrm{kg} \mathrm{ha}^{-1}\right)$

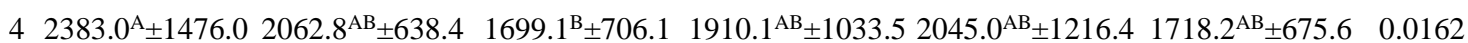

$\begin{array}{llllllll}5 & 1881.4^{\mathrm{A}} \pm 1051.1 & 2026.0^{\mathrm{A}} \pm 1201.5 & 1048.3^{\mathrm{C}} \pm 319.3 & 1322.4^{\mathrm{BC}} \pm 666.1 & 1778.9^{\mathrm{AB}_{ \pm}} \pm 1001.1 & 1123.9^{\mathrm{C}} \pm 374.9 & <0.0001\end{array}$

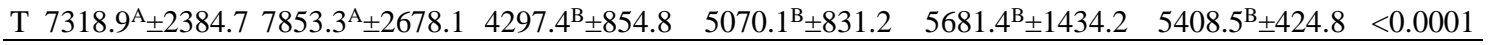

C: Cut (number); A: Average of five cuts; T: Total of five cuts.

Means followed by different letters in the line differ significantly by Tukey Test $(\mathrm{P}<0.05)$.

In comparison to the results of the present study, Mioto et al. (2014) recorded a higher DM production for INIA Escorpio, but lower in Barjumbo and LE 284 after five cuts. LE 284 had also produced less (about $4.6 \mathrm{t} \mathrm{ha}^{-1}$ ) according to the results found by Flores et al. (2008) and Tonetto et al. (2011), but Rocha et al. (2007) indicated a production $40 \%$ higher than those observed, and with a cut less. Hahn et al. (2015) found that, in five cuts, Barjumbo produced less (7.48 t/ha) than in the present study, but INIA Escorpio, Potro, and Winter Star exhibited greater production rates than those observed here.
Even though Tables 2 and 3 illustrate data from different locations (ten and two properties, respectively), in absolute values they indicate that DM production increased in all cultivars until the fourth cut, with a greater decrease $(38.3 \%$, INIA Escorpio) or lower decrease (1.8\%, Barjumbo) from the fourth to the fifth cut. The slowest decline in forage production over the pasture cycle (i.e., the greater productive persistence) is a characteristic whose importance is comparable to that of phytomass production (Malcolm et al., 2014). In addition, the average production of the 
fifth cut (greater than $1,500 \mathrm{~kg} \mathrm{ha}^{-1}$ ) indicated that it would be possible to perform more cuts, if this were the option, enabling an even greater production.

The data referring to the bromatological composition of the forage are presented in Table 4 , considering the first three cuts, i.e., the assessments performed in the ten locations. With regard to $\mathrm{CP}$, there was a significant effect on the second cut. On the average of the cuts, the $\mathrm{CP}$ content of Potro exceeded that of Bar HQ, with no difference between them and the other cultivars. The average content among all materials was $27.4,27.1$ and $25.5 \%$, respectively, from the first to the third cut, and never lower than $24.5 \%$. These values can be considered expressive when grass is the subject of study. Rocha et al. (2007), Marchesan et al. (2015) and Costa et al. (2018) found lower levels of CP in LE 284, Barjumbo and INIA Escorpio, respectively.

Table 4. Content of crude protein, neutral detergent fiber, and total digestible nutrients of ryegrass genotypes in the first three cuts, in ten municipalities of the Western and Northern Plateau regions of the State of Santa Catarina, Brazil

\begin{tabular}{|c|c|c|c|c|c|c|c|}
\hline $\mathrm{C}$ & Bar HQ & Barjumbo & INIA Escorpio & LE 284 & Potro & Winter Star & $\mathrm{p}$-value \\
\hline \multicolumn{8}{|c|}{ Crude Protein $(\%)$} \\
\hline 1 & $26.13 \pm 4.88$ & $27.02 \pm 3.32$ & $28.36 \pm 4.85$ & $27.73 \pm 5.80$ & $29.09 \pm 4.89$ & $26.12 \pm 5.26$ & 0.1028 \\
\hline 2 & $25.17^{\mathrm{B}} \pm 5.52$ & $25.24^{\mathrm{B}} \pm 6.18$ & $27.49^{\mathrm{AB}} \pm 5.08$ & $28.20^{\mathrm{AB}} \pm 4.10$ & $29.52^{\mathrm{A}} \pm 2.84$ & $26.68^{\mathrm{AB}} \pm 5.45$ & 0.0091 \\
\hline 3 & $25.24 \pm 7.67$ & $25.38 \pm 5.98$ & $26.23 \pm 5.39$ & $26.13 \pm 5.77$ & $25.61 \pm 5.95$ & $24.55 \pm 7.12$ & 0.6670 \\
\hline A & $25.51^{\mathrm{B}} \pm 4.39$ & $25.87^{\mathrm{AB}} \pm 4.62$ & $27.37^{\mathrm{AB}} \pm 4.56$ & $27.35^{\mathrm{AB}} \pm 3.96$ & $28.08^{\mathrm{A}} \pm 3.20$ & $25.78^{\mathrm{AB}} \pm 4.60$ & 0.0116 \\
\hline \multicolumn{8}{|c|}{ Neutral Detergent Fiber (\%) } \\
\hline 1 & $38.37 \pm 9.84$ & $35.47 \pm 5.99$ & $37.12 \pm 7.05$ & $38.35 \pm 9.34$ & $39.51 \pm 9.17$ & $38.90 \pm 9.26$ & 0.3838 \\
\hline 2 & $41.06^{\mathrm{A}} \pm 6.53$ & $39.38^{\mathrm{AB}} \pm 5.33$ & $37.69^{\mathrm{B}} \pm 8.77$ & $38.62^{\mathrm{AB}} \pm 7.69$ & $40.30^{\mathrm{AB}} \pm 7.22$ & $40.10^{\mathrm{AB}} \pm 6.22$ & 0.0297 \\
\hline 3 & $43.02^{\mathrm{AB}} \pm 8.30$ & $46.27^{\mathrm{A}} \pm 7.96$ & $41.31^{\mathrm{B}} \pm 7.25$ & $46.20^{\mathrm{A}} \pm 9.43$ & $42.11^{\mathrm{AB}} \pm 7.74$ & $45.15^{\mathrm{AB}} \pm 6.96$ & 0.0095 \\
\hline A & $40.83 \pm 6.42$ & $40.36 \pm 5.25$ & $38.71 \pm 6.46$ & $41.04 \pm 4.88$ & $40.64 \pm 5.81$ & $41.38 \pm 5.36$ & 0.0609 \\
\hline \multicolumn{8}{|c|}{ Total Digestible Nutrients (\%) } \\
\hline 1 & $68.88 \pm 6.56$ & $71.17 \pm 4.53$ & $70.07 \pm 5.51$ & $70.61 \pm 7.07$ & $69.78 \pm 7.26$ & $69.07 \pm 7.46$ & 0.3536 \\
\hline 2 & $67.52 \pm 6.05$ & $69.28 \pm 3.32$ & $69.66 \pm 4.40$ & $70.04 \pm 4.39$ & $68.08 \pm 4.16$ & $68.02 \pm 4.59$ & 0.3477 \\
\hline 3 & $63.48 \pm 3.24$ & $65.47 \pm 5.45$ & $65.39 \pm 5.72$ & $64.80 \pm 4.40$ & $65.39 \pm 4.97$ & $65.26 \pm 4.15$ & 0.6553 \\
\hline A & $66.62 \pm 4.11$ & $68.63 \pm 4.05$ & $68.39 \pm 4.62$ & $68.49 \pm 4.27$ & $67.73 \pm 4.62$ & $67.27 \pm 4.02$ & 0.2895 \\
\hline
\end{tabular}

C: Cut (number); A: Average of three cuts.

Means followed by different letters in the line differ significantly by Tukey Test $(\mathrm{P}<0.05)$.

With respect to NDF, INIA Escorpio exhibited lower content than Bar HQ in the second cut, and Barjumbo and LE 284 in the third cut $(\mathrm{P}<0.05)$. The other cultivars did not differ from those or between themselves. Likewise, there was no difference between the genotypes when the average of the three cuts was assessed. As the cuts were performed, there was a slight increase in the average NDF content (38 to $44 \%$ ), which reached a level of $40.5 \%$ in the set of the three assessments. The contents observed in LE 284 were equivalent to those determined by Rocha $e t$ al. (2007). However, for INIA Escorpio and Barjumbo the values were below than those reported by Costa et al. (2018) and Marchesan et al. (2015), respectively.

There was no effect of the genotypes on TDN contents in any of the cuts and in the average of the three cuts. The average contents varied slightly ( $70 \%$ in the first cut to $65 \%$ in the third), coinciding with the contents of 65 to $71 \%$ levels observed by Kobayashi et al. (2008). The bromatological parameters indicated that this forage had very good nutritional value, with high potential for animal production.

Table 5 shows Pearson's correlations for the variables studied. The quantitative variables DM production, forage height when cutting, and daily DM accumulation rate correlated positively with each other and with NDF contents. On the other hand, they showed negative correlations with $\mathrm{CP}$ and TDN contents. Among the qualitative variables, NDF had a negative relationship with both CP and TDN contents. Only the relationship between $\mathrm{CP}$ and TDN was not significant $(\mathrm{P}>0.05)$. 
Table 5. Pearson's correlation between quantitative and qualitative variables of the ryegrass genotypes production, in the first three cuts, in ten municipalities of the Western and Northern Plateau regions of the State of Santa Catarina, Brazil

\begin{tabular}{lccccc} 
& $\mathrm{CH}$ & $\mathrm{DAR}$ & $\mathrm{CP}$ & $\mathrm{NDF}$ & $\mathrm{TDN}$ \\
\hline \multirow{2}{*}{$\mathrm{DMP}$} & 0.54975 & 0.85832 & -0.42460 & 0.29755 & -0.21430 \\
& $<0.0001$ & $<0.0001$ & $<0.0001$ & $<0.0001$ & 0.0039 \\
$\mathrm{CH}$ & & 0.54898 & -0.36269 & 0.31674 & -0.27206 \\
& & $<0.0001$ & $<0.0001$ & $<0.0001$ & 0.0002 \\
DAR & & -0.33211 & 0.34371 & -0.25021 \\
& & $<0.0001$ & $<0.0001$ & 0.0007 \\
$\mathrm{CP}$ & & & -0.20687 & 0.12882 \\
& & & 0.0053 & 0.0848 \\
$\mathrm{NDF}$ & & & & -0.61190 \\
& & & & $<0.0001$ \\
\hline
\end{tabular}

DMP: dry matter production; $\mathrm{CH}$ : cutting height; DAR: daily dry matter accumulation rate; CP: Crude Protein; NDF: Neutral Detergent Fiber; TDN: Total Digestible Nutrients.

The results found by other studies are in line with the results found in the present study, with a negative relationship between the amount of DM in ryegrass and the content of $\mathrm{CP}$ and NDF (Vandewalle et al., 2003; Müller et al., 2012), and between the levels of CP and NDF (Müller et al., 2012; Wang et al., 2015). A positive correlation between forage accumulation rate and canopy height was reported by Rosa et al. (2013).

\section{CONCLUSION}

The data obtained in two mesoregions of the State of Santa Catarina, Brazil, indicated that the tetraploid cultivars Barjumbo and Bar HQ were more productive than three other tetraploid genotypes and one diploid genotype, either considering three or five cuts. The production of 3.5 to $4.9 \mathrm{tha}^{-1}$ of DM reached until the third cut, performed in the second half of August or in September, indicated that all materials were good options for short-cycle systems, as in the case of models of integration with summer crops, very common in the south region of the country. On the other hand, it should be noted that ryegrass is mostly characterized by a spring growth cycle, and the productions of the fourth and fifth cuts were, on average, $43.5 \%$ higher than the sum of the first three cuts. With the fifth cut occurring in the first half of October, and in view of the slow production decline at this stage, it was concluded that the cultivars were fully adapted to long-term forage systems, with a period of use that extends until November. The productive advantage of Barjumbo and Bar HQ, regardless of the number of cuts, indicated that the eventual higher cost of seeds, typical of tetraploid cultivars, can be fully compensated by greater outcomes in animal performance. However, it should be noted that the diploid LE 284 cultivar was not inferior to the other tetraploid cultivars assessed. The bromatological composition of the forage produced until the third cut (CP above $25 \%$, TDN above $66 \%$, and NDF below $42 \%$ ), with no difference between cultivars, ensures that they are materials of high nutritional value and, therefore, high potential for animal production. In this way, they are especially suitable for herds of great nutritional demand and recognized capacity to respond to the quality of the diet. 


\section{REFERENCES}

ALVARES, C.A.; STAPE, J.L.; SENTELHAS, P.C. et al. Köeppen's climate classification map for Brazil. Meteorol. Zeitschr., v.22, p.711-728, 2013.

CARVALHO, P.C.F.; SANTOS, D.T.; GONÇALVES, E.N. et al. Forrageiras de clima temperado. In: FONSECA, D.M.; MARTUSCELLO, J.A. (Eds.). Plantas forrageiras. Viçosa: UFV, 2013. p.494-537.

CENSO agropecuário 2017 - resultados preliminares. 2018. Disponível em: https://sidra.ibge.gov.br/tabela/6722. Acessado em: 20 set. 2019.

COSTA, O.A.D.; COELHO, R.A.T.; SILVEIRA, F.A. et al. Componentes da biomassa e taxa de acúmulo de cultivares de azevém. In: SIMPÓSIO DE SUSTENTABILIDADE \& CIÊNCIA ANIMAL, 3., 2013, Pirassununga. Anais... Pirassununga: USP, 2013. Disponível em: http://www.sisca.com.br/simposio2013/anais.ph >. Acessado em: 20 set. 2019.

COSTA, O.A.D.; FERREIRA, O.G.L.; SILVA, J.L.S. et al. Yield, structural composition and nutritive characteristics of ryegrass cultivars used to haymaking in Lowland soils. Bioscienc. J., v.34, p.1232-1238, 2018.

FLORES, R.A.; DALL'AGNOL, M.; NABINGER, C.; MONTARDO, D.P. Produção de forragem de populações de azevém anual no estado do Rio Grande do Sul. Rev. Bras. Zootec., v.3, p.118-1175, 2008.

HAHN, L.; MÜHL, F.R.; FELDMANN, N.A. et al. Gramíneas forrageiras anuais de inverno em cultivo estreme e em sobressemeadura em Tifton 85. Encicl. Biosfera, v.11, p.1159-1169, 2015.

KOBAYASHI, H.; TAKAHASHI, Y.; MATSUMOTO, T.; NISHIGUCHI, Y. Changes in nutritive value of Italian ryegrass (Lolium multiflorum Lam.) during overwintering period. Plant Prod. Sci., v.11, p.228-231, 2008.

KRONING, A.B.; PEDRA, W.U.; COSTA, O.A.D. et al. Produtividade de azevém em terras baixas do Litoral Sul do Rio Grande do Sul. Cad. Agroecol., v.9, p.1-4, 2014.
MALCOLM, B.; SMITH, K.F.; JACOBS, J.L. Perennial pasture persistence: the economic perspective. Crop Pasture Sci., v.65, p.713-720, 2014.

MAPA de solos do Brasil. Rio de Janeiro: IBGE, Embrapa Solos, 2001. (Mapa color, escala 1:5.000.000).

MANUAL de calagem e adubação para os Estados do Rio Grande do Sul e de Santa Catarina. Porto Alegre: Comissão de Química e Fertilidade do Solo - RS/SC, 2016. 376p.

MARCHESAN, R.; PARIS, W.; MENEZES, L.F.G. et al. Italian ryegrass cultivars production associated or not with oat black under two postgrazing residues. Semin. Ciênc. Agrárias, v.37, Supl.1, p.2291-2300, 2016.

MARCHESAN, R.; PARIS, W.; TONION, R. et al. Valor nutricional de cultivares de azevém consorciados ou não com aveia sob dois resíduos de pastejo. Rev. Ciênc. Agrovet., v.14, p.254-263, 2015.

MIOTO, D.F.; AIOLFI, R.B.; SOARES, A.B. et $a l$. Produção de forragem de cultivares de azevém anual diploides e tetraploides submetidos ao regime de cortes no município de Pato Branco/PR. In: CONGRESSO BRASILEIRO DE ZOOTECNIA, 24., 2014, Vitória. Anais... Vitória: UFES, 2014. p.12-14.

MÜLLER, L.; MANFRON, P.A.; MEDEIROS, S.L.P. et al. Correlações de Pearson e canônica entre componentes da matéria seca da forragem e sementes de azevém. Rev. Bras. Sementes, v.34, p.86-93, 2012.

OLIVEIRA, L.V.; FERREIRA, O.G.L.; COELHO, R.A.T. et al. Características produtivas e morfofisiológicas de cultivares de azevém. Pesqui. Agropecu. Trop., v.44, p.191197, 2014.

OLIVEIRA, L.V.; FERREIRA, O.G.L.; PEDROSO, C.E.S. et al. Características estruturais de cultivares diploides e tetraploides de azevém. Biosci. J., v.31, p.883-889, 2015.

ROCHA, M.G.; QUADROS, F.L.F.; GLIENKE, C.L. et al. Avaliação de espécies forrageiras de inverno na Depressão Central do Rio Grande do Sul. Rev. Bras. Zootec., v.3, Supl., p.1990-1999, 2007. 
ROSA, A.T.N.; ROCHA, M.G.; PÖTTER, L. et al. Consumo de forragem e desempenho de novilhas de corte recebendo suplementos em pastagem de azevém. Ciênc. Rural, v.43, p.126131, 2013.

SISTEMA brasileiro de classificação de solos. Rio de Janeiro: Embrapa Solos, 2006. 306p.

TCACENCO, F.A. Desempenho de cultivares de Lolium multiflorum Lam. em Lages, Santa Catarina. Pesqui. Agropecu. Gaúcha, v.1, p.119123, 1995.

TONETTO, C.J.; MÜLLER, L.; MEDEIROS, S.L.P. et al. Produção e composição bromatológica de genótipos diploides e tetraploides de azevém. Zootec. Trop., v.29, p.169-178, 2011.
VANDEWALLE, M.; BAERT, J.; CALSYN, E. et al. Analysis of digestibility, nitrogen content and yield in Italian ryegrass (Lolium multiflorum Lam.). In: SYMPOSIUM OF THE EUROPEAN GRASSLAND FEDERATION, 12., 2003, Pleven. Proceedings... Pleven: Bulgarian Association for Grassland and Forage Production, 2003. p.426-428

WANG, J.; COGAN, N.O.I.; PEMBLETON, L.W.; FORSTER, J.W. Variance, inter-trait correlation, heritability and trait-marker association of herbage yield, nutritive values, and morphological characteristics in Italian ryegrass (Lolium multiflorum Lam.). Crop Pasture Sci., v.66, p.973-984, 2015. 